\title{
The Effectiveness of a Strategy Based on Action Research in Developing Translation Skills of Workers' University Students
}

\section{Elsayed Ahmed Mohammad Sadaka}

Assistant Lecturer of English Language

Workers' University

\section{Abstract}

his pre-post experimental study aimed at
investigating the effectiveness of a strategy based
on Action Research in developing English translation skills of Workers' University students, Kafr ElSheikh branch. The participants consisted of 70 students chosen from 1st year Workers' University students, department of industrial affairs in the first semester 2018 - 2019. The researcher used the following instruments: a translation skills checklist, and a pre-posttest on translation skills. The results revealed that there are statistically significant differences at (0.05) between the mean scores of the experimental group students and those of the control group students in the post-test in English translation skills in favor of the experimental group. Furthermore, the results pointed out that there are statistically significant differences at (0.05) between the mean scores of the experimental group students in the pre and post-test of translation skills in favor of the post-test.

Key words: action research, English translation skills.

\section{Introduction}

Language in any human society occupies a great place of care, and attention because of its important roles in the lives of individuals. Learning English has become one of the top priorities of Arab education systems, because modern technology and inventions have made English an essential part of our daily lives. According to Ross (2000), translation is regarded as the fifth skill and the most important social skill as it reinforces communication and understanding. As well, Harmer (2001) stated that the use of both students' 
native language and code switching between two languages are naturally helping things in learning a new language. In addition, Leonardi (2010:17) stated, "translation plays a very important role in an increasingly globalised world and in increasingly multilingual Europe where it is used on daily basis".

Jeket \& Masssey (2003) affirmed that translation process does not rely only on the translator's bilingual competence but also on his/ her ability to analyze the relations between the source language and the target language. Moreover, El-Tantawi (2011:13) viewed translation as "a mental process that requires some mental efforts in two languages. This process moves through a main skill; contrastive linguistic competence". To the same point, Aly, Yehia, \& Abu Eleinein (2015:3) defined translation as "Translation is ultimately a human activity which enables human beings to exchange ideas and thoughts regardless of the different tongues used".

According to PACTE, (2002:43), translation competence is "an underlying knowledge or ability needed to carry out a translation task". Sebokova (2010:8) defined it as "the knowledge and skills the translator must possess in order to carry out translation". For Pym (2011:105), translation competence is "all skills, attitudes, and background knowledge need by a professional translator". Sebokova (2010:7) asserted that translation competence is "a complex concept that requires knowledge of two or more languages and usually consists of two or more sub-competencies". Sriwantaneeyakul (2018:1) affirmed, "Translation ability requires many language skills to produce an accurate and complete text". 
Delisle (1988 cited in Abdel Ghany, 2015:24) pointed out that there are several phases when analyzing the translation process: 1) comprehension, 2) decoding signs, 3) understanding meaning, 4) interpretation, 5) reformulation, 6) analogical reasoning, 7) re-verbalization, and 8) verification.

Mendoza \& ponce (2009) stated that translation process consists of several main stages: planning the translation, comprehension of the source text (decoding), information analysis, transferring its cultural and linguistic components into the context of the target language, translating, and revising and editing.

\section{Translation Models}

1. Two-Phase Model: this model was presented by Bell (1991, cited in Hurtado Albir \& Alves (2009). Bell's Linguistic and Psycholinguistic Model indicated that the process of translation, though complex, requires two main phases of analysis (decoding or comprehension of) the contents of the ST (source text), and synthesis of the ST (source text) information into the TT (target text).

2. Three-Phase Models: according to Hurtado Albir \& Alves (2009), the processes of translation and interpretation involve three major phases: understanding, deverbalisation and re-expression.

3. Multiple-Phase Models: according to Nwachukwu (2017), this model has been distinguished in 1913 by Poincaré. It involves preparation, incubation, illumination and evaluation. Randaccio (2012:83) stated that: "the translator engages in at least five activities, which are commonly considered language learning activities. The five activities are: i) 
Anticipation; ii) Resource Exploitation; iii) Cooperation; iv) Revision; v) Translating

\section{Translation Kinds}

follows:

Jakobson (2012:127) classified translation types as

1. Intralingual translation or rewording is an interpretation of verbal signs by means of other signs of the same language.

2. Interlingual translation or translation proper is an interpretation of verbal signs by means of some other language.

3. Intersemiotic translation or transmutation is an interpretation of verbal signs by means of signs of nonverbal sign systems.

Action research has been commonly used in educational field, yet it remains a controversial term. Action research can be viewed as a powerful practical tool, which individuals can carry out to develop their own professional practice through systematic reflection, enquiry and action. With respect to language skills, action research is regarded as a powerful tool, as it not only sheds light on the complexities of the teaching process in day-to-day life, but it is considered also as the best way to make the policymakers aware of the difficulties of the irrelevant policies imposed upon teachers (Meyers and Rust 2003, cited in Mohan, 2017). Moreover, Hassen (2016) indicated that action research is one of the different approaches of educational research methods.

Burns (2000) pointed out that action research is regarded as an essential tool for school and classroom investigation. He affirmed that the purposes of action research in education fall broadly into categories that 
reflect action research as: a way to solve problems in specific situations, a means of in-service training for the teachers to train them in new skills and methods, a means of devising innovatory approaches of teaching and learning, a means of enhancing the normally poor communications between the practicing teachers and the academic researchers, and a means of finding a preferable substitute to the more subjective, impressionistic approach to problem-solving in the classroom.

The role of action research is not limited to developing reading comprehension as long as it could improve translation skills. Translation depends on the skills of reading and writing; the student must understand what he reads and then form it in a correct written style. Cravo \& Nevas (2007:99) indicated, "This leads us to believe that the use of $\mathrm{A} R$ in translator education and training programs can contribute towards a future generation of committed reflexive professionals. In our view, this will mean a long term investment that may lead to greater insight into long standing problems in TS". Séverine (2008) asserted that Action Research proved to be useful in translator training and encouraged translation studies trainers to engage in continual reflection on their practice. ElTantawi (2011: 5) stated, "Translation is a very important science and art because it conveys the cultures of others. Without translation, we cannot obtain any information about the ancestors". Piotrowska (2013) demonstrated the usefulness and relevance of action research in in translator training.

\section{Statement of the Problem}

The problem of the study is that Workers' University students face some problems in English 
translation skills. Therefore, this research attempts to use action research to develop English translation skills of Workers' University students.

\section{Research Questions}

This research attempted to answer the following main question:

How effective is the use of action research in developing English translation Skills of Workers' University students? they are:

This question is divided into other sub-questions,

1) What are the translation skills needed to be developed for Workers' University students?

2) To what extent is action research strategy effective in developing these translation skills?

\section{Research Hypotheses}

This research examined the following hypotheses:

1) There are statistically significant differences at (0.05) between the mean scores of the experimental group students and those of the control group students in the post-test in translation skills in favor of the experimental group.

2) There are statistically significant differences at (0.05) between the mean scores of the experimental group students in the pre and posttest of some translation skills in favor of the posttest.

\section{The Significance of the Research}

As for Students, action research can help develop students' translation skills. With respect to teachers, action research can help teachers implement new steps, activities, procedures, techniques, and organize 
effective teaching and learning environment concerning development of translation skills. Moreover, action research can help curriculum planners modify, enrich, and design programs that will improve translation skills.

\section{The Objectives of the Research}

The main aim of the current research is to develop translation skills using a strategy based on action research. This aim can be divided into the following objectives:

1) Identifying translation skills needed to be developed for Workers' University students.

2) Identifying the effectiveness of action research in the development of translation skills of Workers' University students.

\section{Delimitations of the Research}

The current research was limited to:

1. Workers' University - Kafr El-Sheikh branch, department of Industrial Affairs, year one during the academic year (2018-2019).

2. Action research based strategy.

3. Translation skills needed to be developed for Workers' University students.

\section{Definition of Terms and Operational Definitions:}

\section{Effectiveness:}

Effectiveness is defined as:

The UNESCO definition is:

Vlãsceanu, L., Grünberg, L., \& Pârlea, D. (2007:54) defined effectiveness (educational) as: "An output of specific review/analyses that measure (the quality of) the achievement of a specific educational goal or the degree to which a higher education institution can be expected to achieve specific requirements". 
Productivity Commission (2013:6) defines effectiveness as "the extent to which stated objectives are met - the policy achieves what it intended to achieve".

The researcher will adopt the following operational definition: effectiveness is defined operationally as the degree of achievement or the amount of change that action research strategy makes on the development of reading comprehension skills and the translation skills in English among Workers' University students as a result of the semi-experimental treatments in the current research.

\section{Action Research:}

McNiff (2010: 8) defined it as: "a term which refers to a practical way of looking at your own work to check that it is as you would like it to be".

According to Wideman (2011:52) Action research is a "process of investigation based on development, execution, and evaluation of experiments".

Coghlan \& Brannick (2014: xix) defined action research as a "family of related approaches that integrate theory and action with a goal of addressing important organizational, community and social issues together with those who experience them".

Wang (2016:958) defined action research as "the combination and interaction of two modes of activityaction and research. The action is located within the ongoing social processes of particular societal context, and typically involves developments and interventions into those processes to bring about improvement and change. The research is located within the systematic observation and analysis of the developments and changes that eventuate in order to identify the 
underlying rationale for the action and to make further changes as required based on findings and outcomes".

For Burns \& Westmacott (2018:16) action research is "a form of systematic inquiry that is usually appealing to teachers as it enables a focus on areas of their own practice that they consider worth investigating".

The researcher will adopt the following operational definition: action research is defined as an organized way to analyze an educational situation to contribute to the development of reading comprehension skills and text translation skills, and to enable students to solve their problems.

\section{Translation:}

Sebokova (2010:6) defined translation of written texts as "a multidisciplinary activity that has been used for communication between members of different cultures since the beginning of writing".

Whyatt (2012:23) affirmed, "Translation is said to be the fifth skill of a bilingual person apart from the basic four skills of reading, listening, speaking and writing".

Abdel Ghany (2015:18) stated, "Translation, as a complex dichotomous and cumulative process, involves a host of activities drawing upon other disciplines related to language, writing, linguistics, and culture".

According to Rahmi (2018:44), "Translation is giving the meaning of words, sentences where it has relationship with the situation and condition at that time".

The researcher will adopt the following operational definition: translation is defined as the 
ability of students of workers' university to transfer meaning from one language to another, i.e. from English to Arabic.

\section{Method}

\section{Participants of the Research}

The participants of the research were 70 students. They were chosen from 1st year Workers' University students, Department of Industrial Affairs in the first semester 2018 - 2019. The students live in an exclusively Arabic-speaking community and have learned English as a foreign language. The students were randomly divided into two groups (experimental group and control group) according to the routine of the students affairs adopted by Workers' University (35 students for the experimental group and 35 students for the control group).

\section{The Research Instruments}

The researcher used the following instruments to achieve the purpose of the research:

- A translation skills checklist to identify translation skills required to be developed for the students of Workers' University in English (prepared by the researcher).

- A pre/posttest on translation skills to evaluate Workers' University students' translation skills. (prepared by the researcher).

\section{Results of the Statistical Analysis:}

\section{Verifying the First Hypothesis of the Research:}

The first hypothesis stated that: "There are statistically significant differences at $(0.05)$ between the mean scores of the experimental group students and those of the control group students in the post-test in translation skills in favor of the experimental group". 
In order to verify this hypothesis, the researcher compared the mean scores of the experimental group students and those of the control group students in translation skills as a whole in the post-test. In addition, the researcher used t-test for independent samples to find out if there were any statistically significant differences between the experimental and control groups after conducting the strategy.

Table 1T-test Results of the Post-test for the Experimental and Control Groups in Overall Translation Skills

\begin{tabular}{lllllll}
\hline Group & N. & Mean & S.D & T-Value & D.F & Sig. \\
\hline Control & 35 & 12.3143 & 3.73986 & \multirow{2}{*}{15.860} & 68 & sig. \\
Experimental & 35 & 29.7714 & 5.33074 & & & \\
\hline
\end{tabular}

In table (1), the t-value is (15.860) which means that there are statistically significant differences at $(0.05)$ between the mean scores of the experimental group students and those of the control group students in the post-test in translation skills in favor of the experimental groupwas. This means that using a strategy based on action research is effective in developing some translation skills of Workers' University students. Therefore, these results prove the first hypothesis of the study.

Table (2) shows that there are statistically significant differences between the mean scores of the experimental group students and those of the control group students in the post-test in favor of the experimental group in the skill of "Getting the main idea of the text", where " $t$ " value is (10.640). Also, it indicates that there are statistically significant differences between the mean scores of the experimental group students and those of the control group students in the post-test in favor of the experimental group in the skill of "Guessing the 
meaning of difficult words", where "t" value is (11.727). In addition, it indicates that there are statistically significant differences between the mean scores of the experimental group students and those of the control group students in the post-test in favor of the experimental group in the skill of "Translating lexical items according to context", where "t" value is (13.383). Likewise, it demonstrates that there are statistically significant differences between the mean scores of the experimental group students and those of the control group students in the post-test in favor of the experimental group in the skill of "Translating the verbs be, have, do, and modal verbs", where " $t$ " value is (12.918).

Table 2: T-test Results of the Post-test for the Experimental and Control Groups in Each Translation Skill

\begin{tabular}{|c|c|c|c|c|c|c|c|}
\hline Skills & Groups & N. & Mean & S.D. & $\mathbf{T}$ & D.F & Sig. \\
\hline \multirow{2}{*}{$\begin{array}{c}\text { Getting the main idea of the } \\
\text { text }\end{array}$} & Cont. & 35 & 1.54 & 0.701 & \multirow{2}{*}{10.640} & \multirow{2}{*}{68} & \multirow{2}{*}{ Sig. } \\
\hline & Exp. & 35 & 3.57 & 0.884 & & & \\
\hline \multirow{2}{*}{$\begin{array}{l}\text { Guessing the meaning of } \\
\text { difficult words }\end{array}$} & Cont. & 35 & 1.49 & 0.658 & \multirow{2}{*}{11.727} & \multirow{2}{*}{68} & \multirow{2}{*}{ Sig. } \\
\hline & Exp. & 35 & 3.80 & 0.946 & & & \\
\hline \multirow{2}{*}{$\begin{array}{l}\text { Translating lexical items } \\
\text { according to context }\end{array}$} & Cont. & 35 & 1.43 & 0.608 & \multirow[b]{2}{*}{13.383} & \multirow[b]{2}{*}{68} & \multirow[b]{2}{*}{ Sig. } \\
\hline & Exp. & 35 & 3.89 & 0.900 & & & \\
\hline \multirow{2}{*}{$\begin{array}{l}\text { Translating the verbs be, } \\
\text { have, do, and modal verbs }\end{array}$} & Cont. & 35 & 1.63 & 0.731 & \multirow{2}{*}{12.918} & \multirow{2}{*}{68} & \multirow{2}{*}{ Sig. } \\
\hline & Exp. & 35 & 4.06 & 0.881 & & & \\
\hline \multirow{2}{*}{$\begin{array}{l}\text { Producing grammatically } \\
\text { structures in both languages }\end{array}$} & Cont. & 35 & 1.51 & 0.742 & \multirow{2}{*}{9.474} & \multirow[b]{2}{*}{68} & \multirow{2}{*}{ Sig. } \\
\hline & Exp. & 35 & 3.40 & 0.914 & & & \\
\hline \multirow{2}{*}{$\begin{array}{c}\text { Translating technical } \\
\text { vocabularies }\end{array}$} & Cont. & 35 & 1.80 & 0.759 & \multirow[b]{2}{*}{13.960} & \multirow[b]{2}{*}{68} & \multirow[b]{2}{*}{ Sig. } \\
\hline & Exp. & 35 & 4.34 & 0.765 & & & \\
\hline \multirow{2}{*}{$\begin{array}{l}\text { Translating technical terms, } \\
\text { and abbreviations }\end{array}$} & Cont. & 35 & 1.46 & 0.561 & \multirow{2}{*}{11.520} & \multirow[b]{2}{*}{68} & \multirow[b]{2}{*}{ Sig. } \\
\hline & Exp. & 35 & 3.37 & 0.808 & & & \\
\hline \multirow{2}{*}{$\begin{array}{l}\text { Identifying the best meaning } \\
\text { that fits into the context in } \\
\text { both languages }\end{array}$} & Cont. & 35 & 1.46 & 0.561 & \multirow[b]{2}{*}{12.170} & \multirow[b]{2}{*}{68} & \multirow[b]{2}{*}{ Sig. } \\
\hline & Exp. & 35 & 3.34 & $\mathbf{0 . 8 3 2}$ & & & \\
\hline
\end{tabular}


Furthermore, it illustrates that there are statistically significant differences between the mean scores of the experimental group students and those of the control group students in the post-test in favor of the experimental group in the skill of "Producing grammatically structures in both languages", where " $\mathrm{t}$ value is (9.474). Moreover, it points out that that there are statistically significant differences between the mean scores of the experimental group students and those of the control group students in the post-test in favor of the experimental group in the skill of "Translating technical vocabularies", where " $t$ " value is (13.960). As well, it shows that there are statistically significant differences between the mean scores of the experimental group students and those of the control group students in the post-test in favor of the experimental group in the skill of "Translating technical terms, and abbreviations", where "t" value is (11.520). Also, it indicates that there are statistically significant differences between the mean scores of the experimental group students and those of the control group students in the post-test in favor of the experimental group in the skill of "Identifying the best meaning that fits into the context in both languages", where " $t$ " value is (12.170).

As it was hypothesized, there are statistically significant differences between the mean scores of the experimental group students and those of the control group students in the post-test in English translation skills in favor of the experimental group. Moreover, the results reveal that the proposed educational strategy has improved English translation skills of the participants, where the experimental group's performance in the posttest was better than that of the 
control group; consequently, the first hypothesis is approved.

\section{Verifying the Second Hypothesis of the Research:}

The second hypothesis stated that: "There are statistically significant differences at $(0.05)$ between mean scores of the experimental group students in the pre-test and the post-test of some translation skills in favor of the post-test".

In order to verify this hypothesis, the researcher compared the mean scores of the experimental group students in both the pre-test and the post-test in overall translation skills. As well, the researcher used paired samples t-test to find out if there were any statistically significant differences between mean scores of the experimental group students in the pre-test and the post-test of some translation skills after conducting the strategy.

Table 3: T-test Results of the Pre-test and the Post-test for the Experimental Group in Overall Translation Skills

\begin{tabular}{lllllll}
\hline Group & N. & Mean & S.D & T-Value & D.F & Sig. \\
\hline Pre-test & 35 & 9.09 & 1.067 & & & \\
Post-test & 35 & 29.77 & 5.331 & 24.896 & 34 & sig. \\
\hline
\end{tabular}

In table (3), the t-value is (24.896). This means that there are statistically significant differences at (0.05) between mean scores of the experimental group students in the pre-test and the post-test of some translation skills in favor of the post-test". This means that using a strategy based on action research is effective in developing some translation skills of Workers' University students in favor of the post-test. Therefore, these results prove the second hypothesis of the study. 
Table 4: T-test Results of the Pre-test and the Post-test for the Experimental Group in Each Translation Skill

\begin{tabular}{|c|c|c|c|c|c|c|c|}
\hline Skills & Groups & N. & Mean & S.D. & $\mathbf{T}$ & D.F & Sig. \\
\hline \multirow{2}{*}{$\begin{array}{l}\text { Getting the main idea of the } \\
\text { text }\end{array}$} & Pretest & 35 & 1.00 & 0.000 & & & \\
\hline & Posttest & 35 & 3.57 & 0.884 & 17.208 & 34 & Sig. \\
\hline \multirow{2}{*}{$\begin{array}{l}\text { Guessing the meaning of } \\
\text { difficult words }\end{array}$} & Pretest & 35 & 1.23 & 0.426 & & & \\
\hline & Posttest & 35 & 3.80 & 0.964 & 15.087 & 34 & Sig. \\
\hline \multirow{2}{*}{$\begin{array}{l}\text { Translating lexical items } \\
\text { according to context }\end{array}$} & Pretest & 35 & 1.11 & 0.323 & & & \\
\hline & Posttest & 35 & 3.89 & 0.900 & 18.012 & 34 & Sig. \\
\hline \multirow{2}{*}{$\begin{array}{l}\text { Translating the verbs be, } \\
\text { have, do, and modal verbs }\end{array}$} & Pretest & 35 & 1.23 & 0.426 & & & \\
\hline & Posttest & 35 & 4.06 & 0.838 & 21.308 & 34 & Sig. \\
\hline \multirow{2}{*}{$\begin{array}{l}\text { Producing grammatically } \\
\text { structures in both languages }\end{array}$} & Pretest & 35 & 1.03 & 0.169 & & & \\
\hline & Posttest & 35 & 3.40 & 0.924 & 14.423 & 34 & Sig. \\
\hline \multirow{2}{*}{$\begin{array}{l}\text { Translating technical } \\
\text { vocabularies }\end{array}$} & Pretest & 35 & 1.46 & 0.611 & & & \\
\hline & Posttest & 35 & 4.34 & 0.765 & 18.315 & 34 & Sig. \\
\hline \multirow{2}{*}{$\begin{array}{c}\text { Translating technical terms, } \\
\text { and abbreviations }\end{array}$} & Pretest & 35 & 1.06 & 0.236 & & & \\
\hline & Posttest & 35 & 3.37 & 0.808 & 17.200 & 34 & Sig. \\
\hline \multirow{2}{*}{$\begin{array}{l}\text { Identifying the best meaning } \\
\text { that fits into the context in } \\
\text { both languages }\end{array}$} & Pretest & 35 & 1.00 & 0.000 & & & \\
\hline & Posttest & 35 & 3.34 & 0.725 & 19.110 & 34 & Sig. \\
\hline
\end{tabular}

Table (4) shows that there are statistically significant differences between the mean scores of the experimental group students in the pre-test and the post-test in favor of the post-test in the skill of "Getting the main idea of the text", where "t" value is (17.208). Also, it indicates that there are statistically significant differences between the mean scores of the experimental group students in the pre-test and the post-test in favor of the post-test in the skill of "Guessing the meaning of difficult words", where " $t$ " value is (15.087). In addition, it indicates that there are statistically significant differences between the mean scores of the experimental group students in the pretest and the post-test in favor of the post-test in the skill 
of "Translating lexical items according to context", where " $\mathrm{t}$ " value is (18.012). Likewise, it demonstrates that there are statistically significant differences between the mean scores of the experimental group students in the pre-test and the post-test in favor of the post-test in the skill of "Translating the verbs be, have, do, and modal verbs", where "t" value is (21.308).

Furthermore, it illustrates that there are statistically significant differences between the mean scores of the experimental group students in the pretest and the post-test in favor of the post-test in the skill of "Producing grammatically structures in both languages", where " $t$ " value is (14.423). Moreover, it points out that that there are statistically significant differences between the mean scores of the experimental group students in the pre-test and the post-test in favor of the post-test in the skill of "Translating technical vocabularies", where "t" value is (18.315). As well, it shows that there are statistically significant differences between the mean scores of the experimental group students in the pre-test and the post-test in favor of the post-test in the skill of "Translating technical terms, and abbreviations", where "t" value is (17.200). Also, it indicates that there are statistically significant differences between the mean scores of the experimental group students in the pretest and the post-test in favor of the post-test in the skill of "Identifying the best meaning that fits into the context in both languages", where "t" value is (19.110).

From the previous results, it became clear that there are statistically significant differences between the mean scores of the experimental group students in the pretest and post-test of some English translation skills in favor of the post-test. Moreover, the results 
reveal that the proposed educational strategy has improved English translation skills of the participants, where the experimental group's performance in the posttest was better than that in the pre-test; consequently, the second hypothesis is approved.

\section{Conclusions}

With reference to the results mentioned above, it was concluded that the present study provided evidence regarding the positive effectiveness of Action Research strategy in developing translation skills of Workers' University as follows:

- The proposed educational strategy (based on Action Research) was effective in developing the translation skills (Getting the main idea of the text, Guessing the meaning of difficult words, Translating lexical items according to context, Translating the verbs be, have, do, and modal verbs, Producing grammatically structures in both languages, Translating technical vocabularies, Translating technical terms, and abbreviations, and Identifying the best meaning that fits into the context in both languages).

- The experimental group students achieved higher levels of performance on the post-test than in the pre-test in translation that indicated the effectiveness of action research strategy.

- The current study showed that the experimental group students who were taught through using the suggested action research strategy were better than the control group students who were taught using the traditional method. The experimental group students achieved higher levels of performance because those students were provided with the opportunity to learn the content of the strategy 
using different steps and activities included in this strategy.

\section{Recommendations}

With respect to the results of the research, the following recommendations are suggested:

1. Workers University should train TEFL instructor with respect to the use of Action Research in order to help their students to translate texts efficiently.

2. Using the suggested strategy (based on Action Research) as a compulsory course for training all the students of Workers' University on translation skills.

3. TEFL instructors should hold workshops to share their experience and views regarding the use of Acion Research in their classrooms.

4. Course designers should consider the inclusion of Action Research strategy when developing TEFL courses.

5. Planning for translation training programs giving priority to practice using Action Research.

6. Students should be motivated and encouraged to think in English as a separate language that differs from their own mother tongue.

7. Students should be motivated to use dictionaries, offline dictionaries, and online dictionaries for any the meaning of difficult words they face.

8. Workers' University should give English instructors continuous training concerning new strategies and techniques of teaching English language.

\section{References}

- Abdel Ghany, A. (2015). Evaluating EFL Student Teachers' Translation Strategies and Writing Performance: A Think-aloud Protocol Study, Ph.D. Dissertation, Faculty of Graduate Studies for Education, Cairo University.

- Aly, M., Yehia, D. \& Abu Eleinein, A. (2015). The Effectiveness of a Suggested Program Based on Pragmatics in Developing some 
Translation Skills of Palestinian English Majors at Al-Aqsa University, Faculty of Education Journal, Ain Shams University, 36(39), 33-60, Egypt.

- Burns, A. \& Westmacott, A. (2018). Teacher to Researcher: Reflections on a New Action Research Program for University EFL Teachers. Profile: Issues Teach. Prof. Dev., 20(1), 15-23. Retrieved on 8 May 2018 from https://doi.org/10.15446/ profile. v20n1.66236

- Burns, R.B. (2000). Introduction to research methods (4th Ed.), SAGE Publications, London.

- Coghlan, D., \& Brannick, T. (2014). Doing Action Research in your Own Organization. Thousand Oaks, CA: Sage Publishing.

- Cravo, A. \& Nevas, J. (2007). Action Research in Translation Studies. The Journal of Specialised Translation, issue 7, pp. 92107.

- El-Tantawi, H. (2011). The Effectiveness of a Remedial program Based on Error Analysis in Developing Secondary School Students' Translation Skills. Unpublished M.A. Thesis. Institute of Arab Research \& Studies: Cairo.

- Harmer, J. (2001). The practice of English Language Teaching. Oxford: Longman.

- Hassen, R. (2016). Female Teachers' Professional Development through Action Research Practice. Journal of Education and Practice, 7(22), 6-18. ISSN 2222-1735 (Paper), ISSN 2222-288X (Online)

- Hurtado Albir, A. \& Alves, F. (2009). Translation as a Cognitive Ability, in J. Munday (Ed.). The Routledge companion to Translation Studies. London: Routledge. 54-73.

- Jakobson, R. (2012). On linguistic aspects of translation. In: Lawrence Venuti, (Ed.). The Translation Studies Reader. London: Routledge, 126-131.

- Jeket, s. \& Masssey, G. (2003). The Puzzle of Translation Skills: Towards an Integration of E Learning and Special Concepts of Computational Linguistics into the Training of Future Translators. Linguistic online, 15(5), 41-55, ISSN 1615-3014.

- Leonardi, V. (2010). Pedagogical Translation as a Naturally Occurring Cognitive and Lingvistic Activity in Foreign Language Learning. Annali Online di Lettere-Ferrara [online], vol. 1-2, p.1728. Retrieved on 12 May 2016, at: http://eprints.unife.it/annali/ lettere/2011voll1-2/leonardi.pdf.

- McNiff, J. (2010). Action Research for Professional Development:

- Concise Advice for New Action Researchers, Teaching Development, the University of Waikato, New Zealand. 
- Mendoza, I. \& Ponce, N. (2009). Proposal for the Analysis of the Source Text in the Comprehension Phase of the Translation Process: Contextualization, and Analysis of Extra-linguistic and Intra-linguistic Aspects. Redit, Numero, vol. 2, 128-150.

- Meyers, E., \& Rust, F. (Eds.). (2003). Taking Action with Teacher

- Research. Portsmouth, NH: Heinemann.

- Mohan, M. (2017). Book Review: Taking Action with Teacher

- Research by Meyers and Rust. i.e.: Inquiry in Education, 9(1), Article 5. Retrieved from: http://digitalcommons.nl.edu/ie/ vol9/ iss $1 / 5$

- Nwachukwu, J. F. (2017). Identifying and Improving Reading Comprehension in the Translation Process: A Visualization Approach, Ph.D. Dissetation, Faculty of Arts and Social Sciences, Stellenbosch University, South Africa.

- PACTE (2002). Exploratory Tests in a Study of Translation Competence. Conference Interpretation and Translation, 4(2), 41-69.

- Piotrowska, M. (2013). Action Research in Translation Studies.

- Self-reflection in translation research training. Miedzy Oryginalem a Przekladem, issue 19-20, 153-167, Germany. Retrieved on 9 March 2019 from https://www.ceeol.com/ search/article-detail?id $=43850$

- Productivity Commission (2013). On Efficiency and Effectiveness: Some Definitions, Staff Research Note, Canberra.

- Pym. A. (2011). Translation Research Terms: a Tentative Glossary for Moments of Perplexity and Dispute. Translation Research, vol.3, 75-110. Tarragona: Intercultural Studies Group, Spain. Retrieved on 30 March 2018 at: http://isg.urv.es/publicity/ isg/publications/trp 3 2011/index.htm

- Rahmi, Z. (2018). Translating Missions in James Worral's game "Grand Theft Auto's Missions". Advances in Language and Literary Studies, 9(1), 44-47. http://dx.doi.org/10.7575/aiac. alls.v.9n.1p.44

- Randaccio, M. (2012). Translation and Language Teaching: Translation as a Useful Teaching Resource, in F. Gori \& C. Taylor (Eds.). Aspetti della didattica e dell'apprendimento delle lingue straniere: contributi dei collaboratori del Centro Linguistico dell'Università di Trieste. Vol.2. Trieste: EUT Edizioni Università di Trieste: 78-91.

- Ross, N. J., 2000. Interference and Intervention: Using Translation in the EFL Classroom. Modern English Teacher, 9(3), 61-66.

- Šeböková, S. (2010). Comparing Translation Competence. M.A. Thesiss, Faculty of Arts, Masaryk University, Czech Republic. 
Retrieved on 30 March 2018 at: http://is.muni.cz/th/146168/ ff $m /$ ?lang=en.

- Séverine Hubscher-Davidson (2008) A Reflection on Action Research Processes in Translator Training, the Interpreter and Translator Trainer, 2(1), 75-92, DOI: 10.1080/1750399X.2008. 10798767

- Sriwantaneeyakul1, S. (2018). Critical Reading Skills and translation Ability of Thai EFL Students: Pragmatic, Syntactic, and Semantic Aspects. English Language Teaching, 11(4), 1-14. Published by Canadian Center of Science and Education. DOI: 10.5539/elt.v11n4p1

- Vlãsceanu, L., Grünberg, L., \& Pârlea, D. (2007). Quality Assurance and Accreditation: A Glossary of Basic Terms and Definitions (Bucharest, UNESCO-CEPES) Revised and Updated Edition. ISBN 92-9069-186-7. Retrieved on 1 January 2019 from: http://unesdoc.unesco.org/images/0013/001346/134621e.pdf

- Wang, W. (2016). Peer Feedback in Chinese College English Writing Class: Using Action Research to Promote Students' English Writing. Journal of Language Teaching and Research, 7(5), 958-966. DOI: http://dx.doi.org/10.17507/jltr.0705.17

- Whyatt, B. (2012). Translation as a Human Skill. Adam Mickiewicz

- University Press. Poznan, ISBN 978-83-232-2504-1. ISSN 05548144.

- Wideman, R. (2011). Empowering Teachers and Schools to Play Their Key Role in Improving Education. Canadian Journal of Action Research, 12(3): 47-59. 